\title{
Preparation and Electrical Properties of $\mathrm{TiO}_{2}$ Films Prepared by Sputtering for a Pulse Power Capacitor
}

\author{
Sang-Shik Park P $^{\dagger}$
}

School of Nano-Materials Engineering, Kyungpook National University, Kyungpook 742-711, Korea

(Received July 6, 2012; Revised September 4, 2012; Accepted September 6, 2012)

\section{스퍼터링에 의한 펄스파워 캐패시터용 $\mathbf{T i O}_{2}$ 박막의 제조 및 전기적특성}

\author{
박 상 식 \\ 경북대학교 나노소재공학부 \\ (2012년 7월 6일 접수 ; 2012년 9월 4일 수정 ; 2012년 9월 6일 채택)
}

\begin{abstract}
$\mathrm{TiO}_{2}$ thin films for a pulse power capacitor were deposited by RF magnetron sputtering. The effects of the deposition gas ratio and thickness on the crystallization and electrical properties of the $\mathrm{TiO}_{2}$ films were investigated. The crystal structure of $\mathrm{TiO}_{2}$ films deposited on $\mathrm{Si}$ substrates at room temperature changed to the anatase from the rutile phase with an increase in the oxygen partial pressure. Also, the crystallinity of the $\mathrm{TiO}_{2}$ films was enhanced with an increase in the thickness of the films. However, $\mathrm{TiO}_{2}$ films deposited on a PET substrate showed an amorphous structure, unlike those deposited on a Si substrate. An X-ray photoelectron spectroscopy(XPS) analysis revealed the formation of chemically stable $\mathrm{TiO}_{2}$ films. The dielectric constant of the $\mathrm{TiO}_{2}$ films as a function of the frequency was significantly changed with the thickness of the films. The films showed a dielectric constant of $100 \sim 110$ at $1 \mathrm{kHz}$. However, the dissipation factors of the films were relatively high. Films with a thickness of about $1000 \mathrm{~nm}$ showed a breakdown strength that exceeded $1000 \mathrm{kV} / \mathrm{cm}$.
\end{abstract}

Key words : Pulse power capacitor, $\mathrm{TiO}_{2}$, Breakdown strength, R.f. sputtering, Dielectric constant

\section{1. 서 론}

펄스파워 캐패시터는 최근 화석연료를 대체할 에너지 에 대한 관심으로 수요가 증가하고 있는 하이브리드 및 전기 자동차나 태양광발전, 풍력발전용의 인버터기기에 필수적으로 사용된다. 펄스파워 캐패시터는 높은 에너지 밀도를 요구하는 전력전자, 펄스파워 등의 응용분야가 확 대되어, 전원장치 등에 광범위하게 이용되고 있으며 수요 가 급격히 증가하고 있다. ${ }^{1,2)}$ 현재 사용되고 있는 펄스파 워용 캐패시터는 PET(Polyethylene terephthalate)와 PP(Polypropylene)와 같은 유전체를 사용하는 폴리머 필름 캐패시 터가 많이 사용되고 있는데, 지속적으로 더 높은 에너지 밀도를 갖는 캐패시터가 요구되고 있다. 그런데 PET와 $\mathrm{PP}$ 와 같은 유전체는 절연파괴강도는 크지만 2 3의 작은 유전상수를 가지고 있어 ${ }^{3)}$ 고에너지밀도를 요구하는 현재 의 펄스파워 캐패시터를 개선하기엔 한계가 있다. 캐패시

\footnotetext{
${ }^{\dagger}$ Corresponding author : Sang-Shik Park

E-mail : parkss@knu.ac.kr

Tel : +82-54-530-1411 Fax : +82-54-530-1418
}

터의 에너지밀도는 아래 (1)식과 같이 표현할 수 있다.

$$
J=\frac{1}{2} \varepsilon_{0} \varepsilon_{r} E_{b}^{2}
$$

$\mathrm{J}$ 는 에너지밀도 $\left(\mathrm{J} / \mathrm{cm}^{3}\right), \varepsilon_{0}$ 는 진공의 유전상수 $\left(8.85 \times 10^{-12} \mathrm{~F} / \mathrm{m}\right)$, $\varepsilon_{\mathrm{r}}$ 는 유전체의 유전상수, $\mathrm{E}_{\mathrm{b}}$ 는 유전체의 절연파괴강도 $(\mathrm{V} / \mathrm{m})$ 이다. 그러므로 캐패시터가 높은 에너지밀도를 갖기 위해 서는 높은 유전율과 높은 절연파괴강도가 필요하다.

한편, $\mathrm{TiO}_{2}$ 박막은 양호한 광학적, 전기적, 화학적 성질 로 인해, 광촉매, 광학코팅, 태양전지, 캐패시터 유전체 등 다양한 분야에서 널리 연구되고 있다. ${ }^{4-7)}$ 다양한 유전체 재료중 $\mathrm{TiO}_{2}$ 는 약 100 정도의 상대적으로 높은 유전상수 와 $100 \mathrm{kV} / \mathrm{cm}$ 이상의 높은 절연파괴강도를 보이기 때문 에 고에너지밀도 캐패시터에의 적용을 위한 유전체로 관 심을 받아왔다. ${ }^{89}$

본 연구에서는 종래의 폴리머 필름캐패시터의 구조를 유 지하면서 $\mathrm{TiO}_{2}$ 유전체막을 적용한 캐패시터의 제조를 목 표로 하였다. 캐패시터를 제조하기 위해서는 롤투롤(roll to roll) 공정을 이용하여 연속적인 유전체막의 증착이 요 구되며, 기판으로 사용할 $\mathrm{PET}$ 는 통상 $125^{\circ} \mathrm{C}$ 까지의 사용 
온도 한계로 인해 증착중에 수축이 일어나지 않도록 기 판의 냉각이 필요하다. 고에너지밀도 캐패시터의 요구 성 능을 만족시키기 위한 유전체의 제조를 위해 $\mathrm{TiO}_{2}$ 박막 을 r.f. magnetron sputtering 방법으로 증착하였다. 캐패시 터 시작품 제작에 앞서 수십 $\mathrm{nm}$ 수 $\mu \mathrm{m}$ 두께의 $\mathrm{TiO}_{2}$ 박막 을 $\mathrm{Si}$ 및 $\mathrm{PET}$ 기판에 증착 가스비 $\left(\mathrm{Ar}: \mathrm{O}_{2}\right)$ 및 막의 두께 를 달리하여 증착한 후, 성장거동 및 전기적 특성을 분석 하여 펄스파워 캐패시터에의 적용가능성을 평가하였다.

\section{2. 실험방법}

$\mathrm{TiO}_{2}$ 박막 증착을 위한 타겟은 고순도의 $\mathrm{TiO}_{2}$ 분말 (>99.9\%)을 이용하여 분말소결법에 의해 직경 2 인치로 제 조하여 사용하였다. $\mathrm{PET}(\mathrm{SKC})$ 및 $\mathrm{Si}(\mathrm{LG}$ Siltron) 기판위에 증착가스비와 막 두께를 달리하여 $\mathrm{TiO}_{2}$ 박막을 스퍼터링 한 후 막 성장 거동을 확인하였다. PET 기판은 열변형을 방지하기 위하여 냉각수가 순환하는 기판홀더에 직접 부 착하여 사용하였다. 타겟과 기판사이의 거리와 인가전력 이 적정하지 않으면 PET기판의 열변형이 유발되기 때문 에 예비실험을 통해 타겟-기판간 거리 및 인가전력 범위 를 결정하였다. 스퍼터링 챔버를 $5 \times 10^{-6} \mathrm{Torr}$ 로 배기한 후, $\mathrm{Ar}$ 과 $\mathrm{O}_{2}$ 가스를 주입하였으며 타겟은 조성의 균질성 확 보와 표면의 오염물을 제거하기 위하여 30 분 동안 선스 퍼터링 하였다. 증착압력은 $\mathrm{MFC}$ 를 통해 $\mathrm{Ar}$ 과 $\mathrm{O}_{2}$ 가스를 독립적으로 주입하였고, 주밸브의 개폐를 조절하여 $30 \mathrm{mTorr}$ 로 조절한 후 증착을 진행하였다. 막 두께는 동일 증착조 건에서 시간을 달리하여 조절하였으며, 상세한 증착조건 을 Table 1에 나타내었다. 제조된 $\mathrm{TiO}_{2}$ 박막의 결정구조는 $\mathrm{Cu} \mathrm{Ka}$ radiation과 $\mathrm{Ni}$ 필터를 사용한 X-ray 회절장치 (XRD, Panalytical X pert pro)를, 박막의 미세구조는 주사 전자현미경(SEM-EDX, Jeol, JSM-6700F)을 이용하여 분석 하였다. 박막의 표면형상은 SPM(Digital instrument, NanoScope) 을, 화학조성 및 결합상태의 확인은 XPS(ULVAC-PHI, Quantera SXM)를 이용하여 분석을 실시하였다.

전기적 특성을 측정하기 위해 $\mathrm{Al}$ 이 증착된 $\mathrm{PET}$ 기판에 $\mathrm{TiO}_{2}$ 박막을 증착한 후, 마스크를 사용하여 상부전극으로 $0.1 \sim 1 \mathrm{~mm}$ 의 직경을 갖는 $\mathrm{Al}$ 을 약 $100 \mathrm{~nm}$ 의 두께로 $\mathrm{dc}$ sputtering법으로 증착하여 MIM(metal-insulator-metal) 구조

Table 1. Sputtering Conditions of $\mathrm{TiO}_{2}$ Thin Films

\begin{tabular}{ll}
\hline Target-substrate distance & $60 \mathrm{~mm}$ \\
Substrate & PET, Si \\
Base pressure of chamber & $5 \times 10^{-6}$ Torr \\
Chamber pressure & $30 \mathrm{mTorr}$ \\
Applied power & $200 \sim 300 \mathrm{~W}$ \\
Plasma gas flow $\left(\mathrm{Ar}_{2} \mathrm{O}_{2}\right)$ & $1: 0,1: 1$ \\
Substrate temperature & Room temp. \\
\hline
\end{tabular}

를 갖도록 하였다. 유전상수 및 유전손실의 주파수 특성 (C-F)은 impedance gain phase analyzer(HP 4194A)를 이 용하였고, 누설전류특성(I-V)은 picoammeter(HP 4140B)를 이용하여 $0.1 \mathrm{~V}$ 스텝, $0.1 \mathrm{~s}$ 지연시간 조건에서 측정하였다.

\section{3. 결과 및 고찰}

Fig. 1 은 $\mathrm{Si}$ 기판위에 $\mathrm{Ar}$ 과 $\mathrm{O}_{2}$ 가스비에 따라 증착한 $\mathrm{TiO}_{2}$ 박막의 SEM 표면 및 단면 이미지를 보인다. Fig. 1(a) 및 (b)는 $\mathrm{Ar}$ 과 $\mathrm{O}_{2}$ 가스비가 $1: 0$, Fig. 1(c) 및 (d)는 1:1인 조건에서 증착한 막이다. $\mathrm{Ar}$ 가스만으로 증착한 막은 $\mathrm{O}_{2}$ 가스와 같이 증착한 막에 비해, 표면 미세구조가 다소 불 규칙한 형상을 보이고, 더 두꺼운 막으로 성장하였다. 두 시편 모두 상온에서 증착했음에도 미세하지만 분명한 결 정립형상을 보였고, 단면 구조는 특징없는 비정질 구조가 아닌 주상정구조를 보였다. $200 \mathrm{~W}$ 의 전력에서 $\mathrm{Ar}: \mathrm{O}_{2}=$ $1: 0$ 및 $1: 1$ 인 박막은 각각 3.04 및 $1.97 \mathrm{~nm} / \mathrm{min}$ 의 비교적 낮은 증착속도를 보였다. $\mathrm{Ar}: \mathrm{O}_{2}=1: 0$ 인 조건보다 $1: 1$ 인 조 건에서 증착속도가 감소하는 이유는 총압력이 동일한 가 운데 증착가스의 산소분압이 증가함에 따라 스퍼터링 효 율이 감소하기 때문이라고 할 수 있다. ${ }^{10)} \mathrm{Ar}: \mathrm{O}_{2}=1: 1$ 인 조건에서 증착한 막은 $\mathrm{Ar}$ 가스만으로 증착한 막에 비해 더 작은 결정립으로 구성되었으며, Fig. 5의 AFM 결과에 보인 것처럼 매끈한 표면조직을 보이는데 이는 증착속도 의 감소로 인해, 기판위에 부착하는 원자들이 안정한 에 너지 배열로 위치하는데 더 충분한 시간을 갖는 것이 한 요인이 될 수 있다. ${ }^{11)}$

Fig. 2는 $\mathrm{Ar}$ 과 $\mathrm{O}_{2}$ 가스비를 달리하여 증착한 Fig. 1에서 의 $\mathrm{TiO}_{2}$ 막의 $\mathrm{XRD}$ 패턴을 보인다. 상온에서 증착했음에
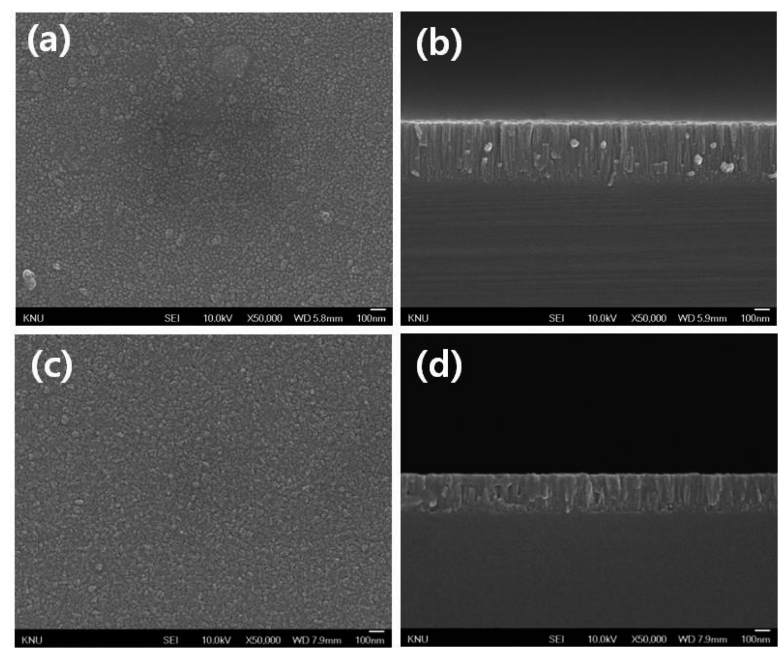

Fig. 1. SEM images of $\mathrm{TiO}_{2}$ thin films deposited on $\mathrm{Si}$ substrate at different gas ratio: (a) and (b) Ar: $\mathrm{O}_{2}=1: 0$ and (c) and (d) Ar: $\mathrm{O}_{2}=1: 1$. 


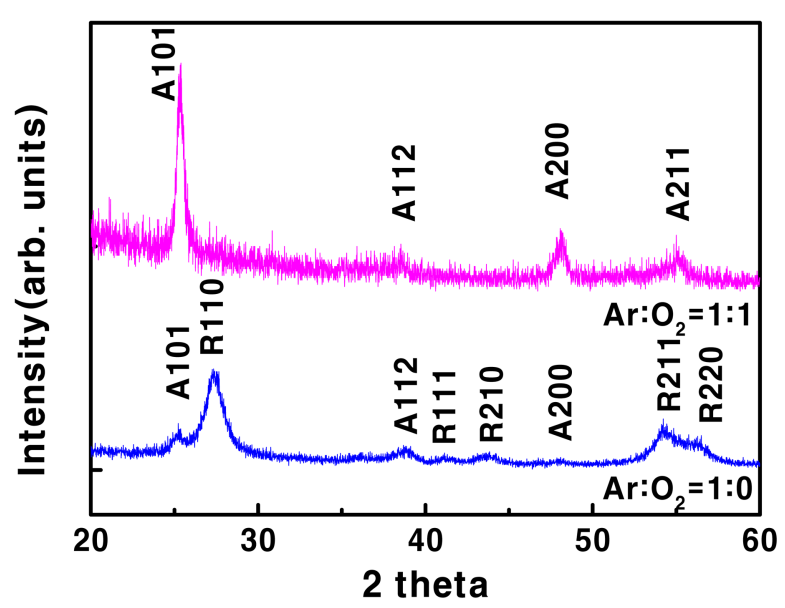

Fig. 2. XRD patterns of $\mathrm{TiO}_{2}$ thin films deposited on $\mathrm{Si}$ substrate at different gas ratio.
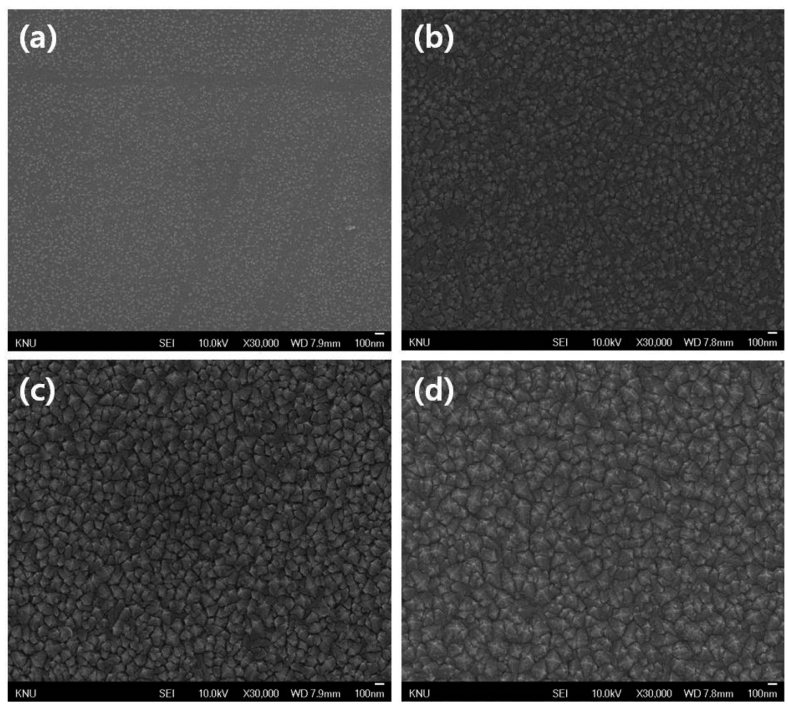

Fig. 3. SEM surface images of $\mathrm{TiO}_{2}$ films of different thickness deposited on Si substrates: (a) $540 \mathrm{~nm}$, (b) $938 \mathrm{~nm}$, (c) $1491 \mathrm{~nm}$, and (d) $1837 \mathrm{~nm}$.

도 두 시편 모두 결정질 피크를 보인다. 지수의 $\mathrm{A}$ 표시는 Anatase상을, R은 Rutile상을 의미하는데, Ar만으로 증착 한 시편의 경우, 피크세기는 크지 않으나 Rutile상과 일부 Anatase상이 혼재함을 보이고 $\mathrm{Ar}$ 과 $\mathrm{O}_{2}$ 가스비가 1:1일 경우 Rutile상은 사라지고 anatase상으로만 구성되었다. $\mathrm{TiO}_{2}$ 타겟을 사용한 PLD(pulsed laser deposition)법 ${ }^{22}$ 과 $\mathrm{Ti}$ 타겟을 사용한 반응성 스퍼터링법 ${ }^{13,14)}$ 으로 $\mathrm{TiO}_{2}$ 박막 을 증착 시, 산소분압이 결정구조의 변화를 유발하는 것 으로 보고하는데, 산소분압이 증가함에 따라 Rutile 상은 적어지고 Anatase상으로 변화하는 것이 일반적이다. $\mathrm{TiO}_{2}$ 타겟을 사용하여 스퍼터링한 본 결과에서도 같은 경향을 보였다.

Fig. 3은 $\mathrm{Si}$ 기판에 $\mathrm{Ar}: \mathrm{O}_{2}=1: 1$ 의 가스비로 증착한 $\mathrm{TiO}_{2}$ 박막의 SEM 표면이미지를 보인다. 막 두께에 따른
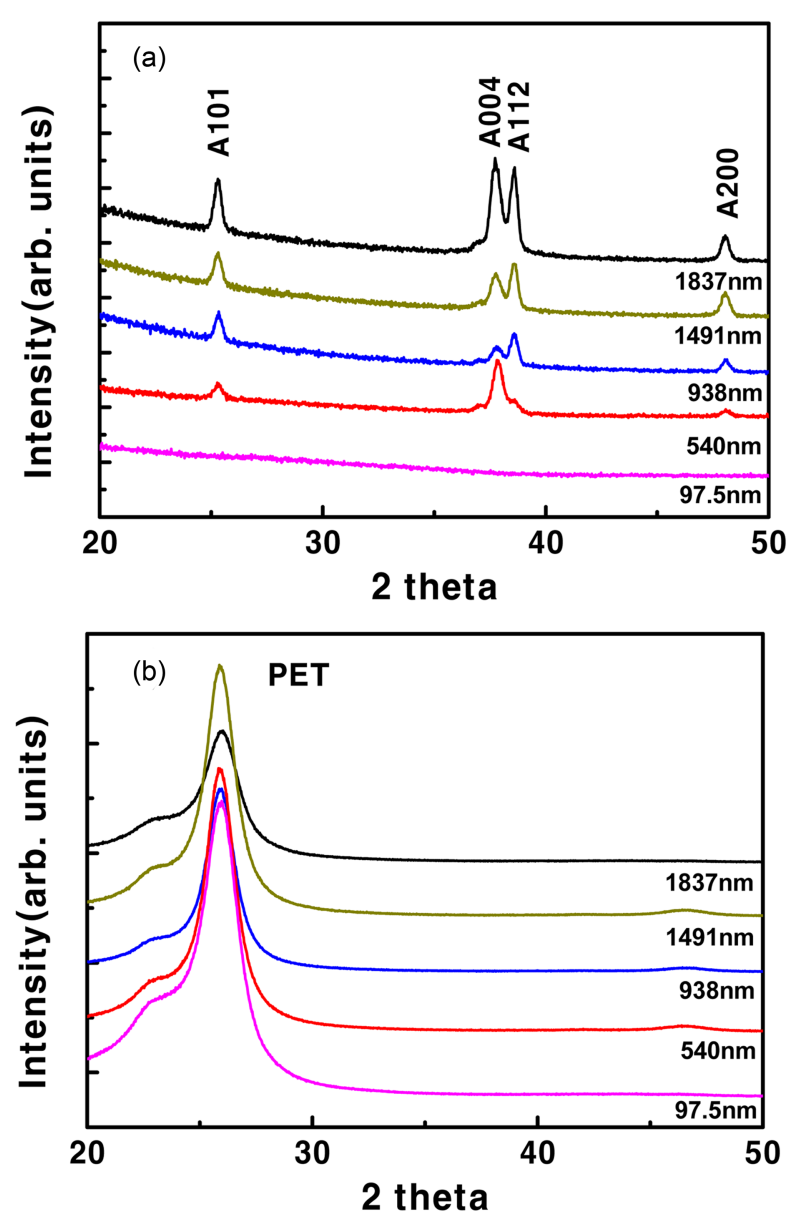

Fig. 4. XRD patterns of $\mathrm{TiO}_{2}$ films of different thickness deposited on (a) Si and (b) PET substrates.

미세구조의 변화를 확인하기 위해 $300 \mathrm{~W}$ 의 전력으로 증 착시간을 1 3시간으로 조절하여 두께가 다른 박막을 제 조하여 표면을 관찰하였다. 시편은 각각 $540,938,1491$, $1837 \mathrm{~nm}$ 의 두께를 갖는데, 두께가 증가함에 따라 결정립 크기가 비례하며 증가함을 보이고 표면 결정립들은 피라 미드형태의 각진 형상으로 성장하였다. 여기에 각 시편의 단면이미지를 보이지는 안았으나 표면결정립 크기에 비 례하여 Fig. 1(b) 및 (d)의 형상을 갖는 주상정의 직경이 증가함을 보였다. 즉, $\mathrm{Si}$ 기판에 증착한 $\mathrm{TiO}_{2}$ 박막의 경우, 상온에서 증착하여도 증착시간에 따라 두께의 증가뿐 아 니라 결정립 크기가 동시에 성장함을 보였다. 이는 막의 두께가 증가함에 따라 기판에 초기 핵생성된 많은 미세 결정립들이 낮은 에너지상태의 우선 성장방향을 갖는 주 상정들이 시간에 따라 지속적으로 성장함에 기인한다. ${ }^{15)}$

Fig. 4는 $\mathrm{Si}$ 및 $\mathrm{PET}$ 기판위에 두께를 달리하여 증착한 $\mathrm{TiO}_{2}$ 막의 XRD 패턴을 보인다. $1: 1$ 의 $\mathrm{Ar}: \mathrm{O}_{2}$ 가스비에서 증착한 $\mathrm{TiO}_{2}$ 막들은 모두 Anatase상으로 형성되었다. Fig. 4(a) 의 $\mathrm{Si}$ 기판에 증착한 $\mathrm{TiO}_{2}$ 막의 경우, $\mathrm{TiO}_{2}$ 막의 두께에 따 라 피크세기가 변하는 특성을 보이는데, Fig. 3의 SEM 이 
미지로부터 예상할 수 있는 것처럼 두께가 증가함에 따 라 결정립도가 증가하고 그로 인해 피크 세기가 증가함 을 보인다. $25.3^{\circ}$ 에서 나타나는 A101 피크의 반가폭 $(\mathrm{FWHM})$ 을 확인한 결과, 두께가 증가함에 따라 $0.48^{\circ}$ 에서 $0.37^{\circ}$ 로 점차 감소하여 결정화도가 증가하였고 $\mathrm{SEM}$ 의 결 정립도 변화 경향과도 일치하였다. 그러나 막의 두께가 약 $100 \mathrm{~nm}$ 이하일 때는 결정질 피크를 보이지 않아 결정 화도가 두께에 크게 의존함을 알 수 있다. 캐패시터에의 적 용을 위해 유연성기판의 적용을 목표로 하는데, Fig. 4(b)의 PET 기판에 증착한 $\mathrm{TiO}_{2}$ 막의 경우, $2 \theta=20 \sim 30^{\circ}$ 범위에 서 PET 피크만이 관찰되며, 막 두께에 무관하게 비정질 로 성장하였다. 다양한 응용을 위해 PET 기판에 $\mathrm{TiO}_{2}$ 막 의 제조가 진행되었는데, $\mathrm{PET}$ 위에 증착한 $\mathrm{TiO}_{2}$ 막의 경우, 대부분 비정질 막으로 성장하는 것으로 보고된다. ${ }^{16,17)}$ 따 라서 펄스파워 캐패시터에의 적용을 위해 PET 기판에 증 착하는 $\mathrm{TiO}_{2}$ 막은 비정질의 형태로 적용된다고 할 수 있다. 박막의 표면형상은 $\mathrm{TiO}_{2}$ 막의 전기적 성질에 영향을 미 치는 중요한 변수이므로, $\mathrm{PET}$ 기판위에 증착한 $\mathrm{TiO}_{2}$ 막 의 표면형상을 $\mathrm{AFM}$ 을 이용하여 $2 \times 2 \mu \mathrm{m}$ 면적을 스캔하 여 관찰하였다. Fig. 5는 $\mathrm{Ar}: \mathrm{O}_{2}$ 비를 달리하여 PET 위에 증착한 $\mathrm{TiO}_{2}$ 막의 $\mathrm{AFM}$ 이미지를 보인다. Fig. 5(a)의 $1: 0$ 에서 증착한 $\mathrm{TiO}_{2}$ 막은 미세한 결정립 구조가 관찰되며, $3.9 \mathrm{~nm}$ 의 평균거칠기를 보였다. Fig. 1 의 $\mathrm{Si}$ 기판위에 증 착한 $\mathrm{TiO}_{2}$ 막의 $\mathrm{SEM}$ 이미지에서는 $1: 0$ 의 가스비에서 증 착한 막에 비해 $1: 1$ 의 조건에서 증착한 막이 더 미세한 결정립을 보였다. Fig. 5(b)의 1:1의 가스비에서 PET 기판 위에 증착한 $\mathrm{TiO}_{2}$ 막의 $\mathrm{AFM}$ 이미지에서는 결정립이 구분 되지 않는 표면형상을 가지고 성장하였고 $\mathrm{TiO}_{2}$ 막의 평균
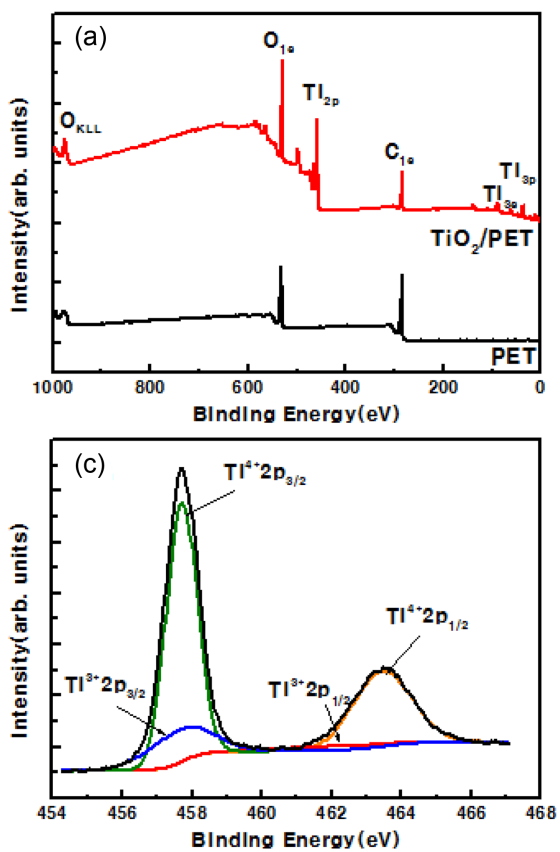

Fig. 5. AFM images of $\mathrm{TiO}_{2} / \mathrm{PET}$ films deposited at different
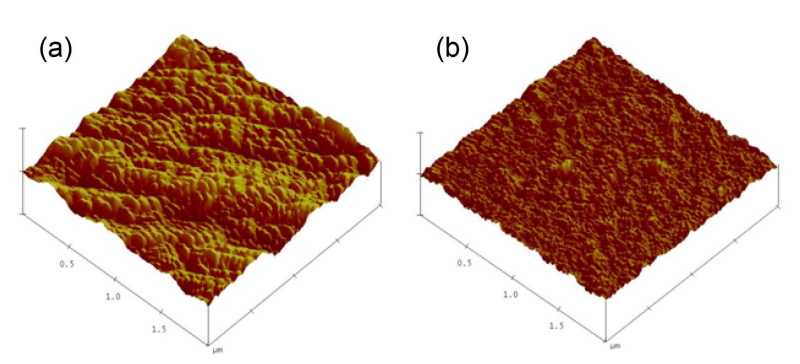
gas ratio of $\mathrm{Ar}_{2} \mathrm{O}_{2}$; (a) $1: 0$ and (b) $1: 1$.

거칠기는 $2.1 \mathrm{~nm}$ 를 보여 더 매끈한 표면 미세구조를 보였 다. 즉, 산소분압이 증가함에 따라 거칠기가 작아지는 결 과를 보였다. 또한, $\mathrm{TiO}_{2}$ 막의 증착 후 테이프 테스트를 통 해 부착력을 확인하였는데, 탈착이 일어나지 않는 양호한 부착성을 보였다.

Fig. 6은 $\mathrm{Ar}: \mathrm{O}_{2}=1: 1$ 의 가스비에서 $\mathrm{PET}$ 기판위에 증 착한 $\mathrm{TiO}_{2}$ 박막의 XPS 스펙트럼을 보인다. Fig. 6(a)는 $\mathrm{PET}$ 기판 및 증착한 $\mathrm{TiO}_{2}$ 박막의 wide scan을, Fig. 6(b) 는 $457.7,463.6 \mathrm{eV}$ 의 Ti2p와 $529.1 \mathrm{eV}$ 에서의 $\mathrm{O} 1 \mathrm{~s}$ 피크의 스펙트럼을 보인다. Fig. 6(c)는 Ti2p의 두 피크를 457.59, $457.66,461.92,463.41 \mathrm{eV}$ 에서 4 개의 피크로 분리한 결과 이며, 각각은 $\mathrm{Ti}^{3+} 2 \mathrm{p}_{3 / 2}, \mathrm{Ti}^{4+} 2 \mathrm{p}_{3 / 2}, \mathrm{Ti}^{3+} 2 \mathrm{p}_{1 / 2}, \mathrm{Ti}^{4+} 2 \mathrm{p}_{1 / 2}$ 로 대 응된다. ${ }^{18,19)} \mathrm{TiO}_{2}$ 박막의 산화상태를 확인하기 위하여 $\mathrm{Ti}^{3+}$ 와 $\mathrm{Ti}^{4+}$ 와 대응하는 피크의 면적비 $\left(\mathrm{Ti}^{3+} 2 \mathrm{p}_{3 / 2} / \mathrm{Ti}^{4+} 2 \mathrm{p}_{3 / 2}\right)$ 와 $\left(\mathrm{Ti}^{3+} 2 \mathrm{p}_{1 / 2} / \mathrm{Ti}^{4+} 2 \mathrm{p}_{1 / 2}\right)$ 를 확인한 결과, Gauss-Lorentz 함수를 이용시 오차가 있지만 각각 0.26과 0.1을 나타내어 $\mathrm{TiO}_{2}$ 박막의 표면은 주로 $\mathrm{Ti}^{4+}$ 상태로 형성되었음을 알 수 있다.

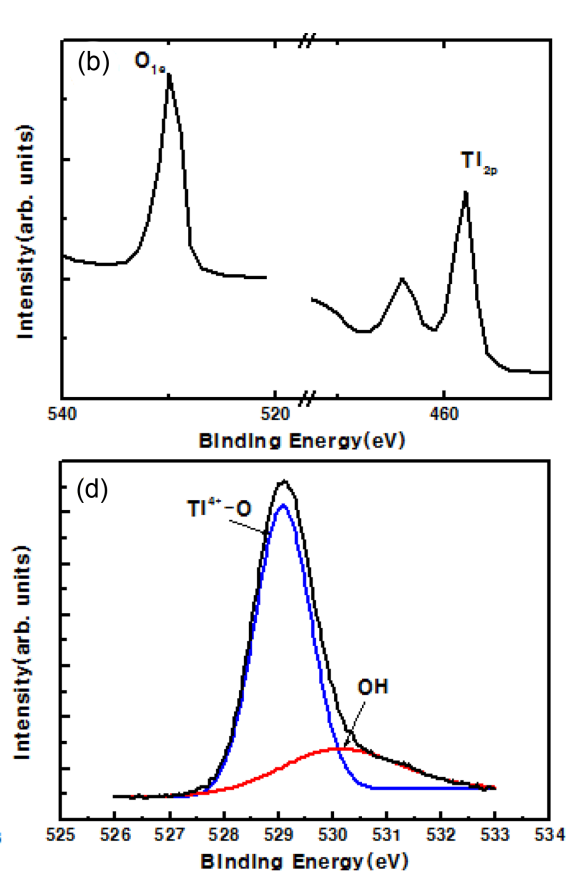

Fig. 6. XPS spectra for (a) wide scan, (b) O1s and Ti2p, (c) Ti2p, and (d) O1s obtained from $\mathrm{TiO}_{2}$ film deposited on PET substrates. 

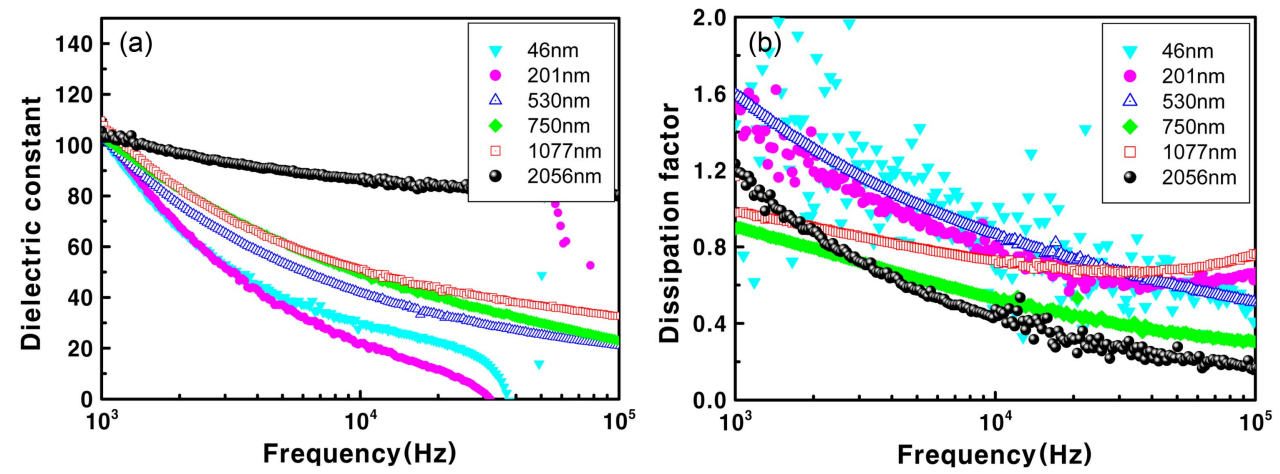

Fig. 7. (a) Dielectric constant and (b) dissipation factor of $\mathrm{TiO}_{2}$ films with different thickness on PET substrate.

Fig. 6(d)는 $529.1 \mathrm{eV}$ 의 $\mathrm{O} 1 \mathrm{~s}$ 피크를 529.12 와 $530.15 \mathrm{eV}$ 에 서 두 개의 피크로 분리한 결과이며 각각은 $\mathrm{TiO}_{2}\left(\mathrm{Ti}^{4+}-\mathrm{O}\right)$ 와 $\mathrm{OH}^{\circ}$ 에 기인한 것으로 볼 수 있다. ${ }^{20)}$ 이들의 면적이 차 지하는 비율은 각각 76.2 와 $23.8 \%$ 를 보여 표면의 수산기 $\left(\mathrm{OH}^{-}\right)$보다는 $\mathrm{Ti}^{4+}$ 와 결합된 산소임을 알 수 있다. 이러한 결과는 PET 표면위에 $\mathrm{TiO}_{2}$ 박막이 화학적으로 안정한 결 합상태로 성장했음을 의미한다.

Fig. 7은 약 46 2056 nm 범위에서 두께를 달리하여 PET 기판에 제조한 $\mathrm{TiO}_{2}$ 박막의 유전상수와 유전손실의 주파 수 의존성을 보이고 있다. Fig. 7(a)로부터 $1 \mathrm{kHz}$ 에서 $1 \mathrm{MHz}$ 의 주파수 영역에서 공진주파수대까지 주파수 증가 에 따라 유전상수가 감소하는데 $1 \mathrm{kHz}$ 에서는 두께에 무 관하게 100 110 정도의 유전상수를 보이다가 두께가 얇 은 박막 일수록, 주파수 증가에 따라 급하게 감소하는 특 징을 보인다. M. Takeuchi ${ }^{9)}$ 등은 두께가 얇은 비정질 $\mathrm{TiO}_{2}$ 막에서는 작은 유전상수를 보이다가 두께증가에 따 라 유전상수가 증가하고 약 $1 \mu \mathrm{m}$ 두께 이상에서 약 100 정도의 값에서 포화되는 것으로 보고하는데 본 연구에서 도 Fig. 4에 보인 것처럼 두께가 증가함에 따라 결정립도 가 증가하고, 이로 인해 유전상수가 증가하는 것으로 판 단된다. Fig. 7(b)의 유전손실은 두께에 따른 경향성을 찾 기는 어렵고 대체적으로 높은 유전손실값을 보이며 얇은 두께의 막에서 더욱 불안정한 값을 보였다. 유전손실값은 타 연구자에 의해 r.f. 스퍼터증착으로 제조된 박막 ${ }^{22)}$ 과는 유사수준이고, 소결법에 의해 제조된 $100 \mu \mathrm{m}$ 후막 ${ }^{21)}$ 에 비 해서는 매우 높은 값을 보였다. 박막의 유전손실에 영향 을 주는 구조적 결함은 박막과 전극 사이의 계면이나 표 면에서 격자붕괴 혹은 표면형상에 의해 유발되는 것으로 보고되는데, ${ }^{22}$ 박막표면과 전극계면의 안정화가 필요할 것으로 판단된다.

Fig. 8은 두께를 달리하여 PET 기판에 제조한 $15 \sim 2056 \mathrm{~nm}$ 의 두께를 갖는 $\mathrm{TiO}_{2}$ 박막들의 인가전계에 따른 누설전 류거동을 보이고 있다. 박막의 두께가 증가할수록 누설전 류밀도는 동일 전계에서 더 증가하는 경향을 보이고 있 다. 일반적으로 누설전류는 결정화도, 결정립도, 표면거칠

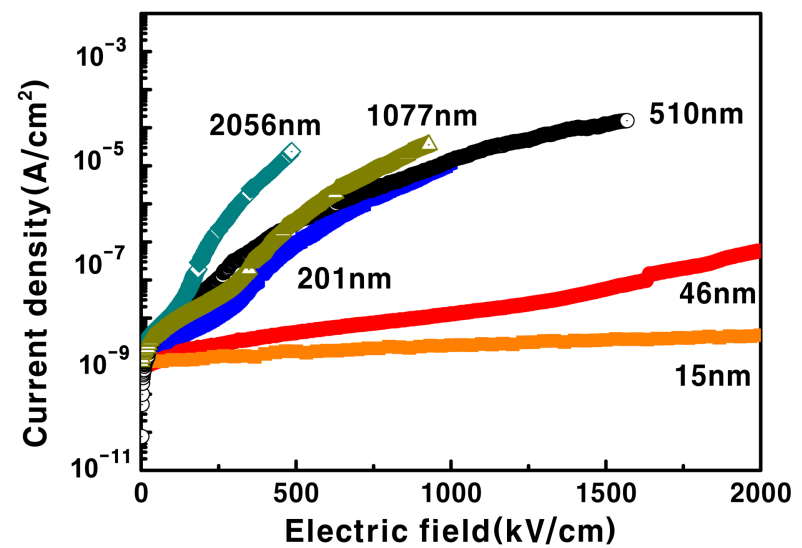

Fig. 8. Leakage current behavior of $\mathrm{TiO}_{2}$ films deposited on PET substrate as a function of thickness.

기 등에 의해 영향을 받는데, 결정립도가 커짐에 따라 표 면거칠기도 증가하고 이에 따라 누설전류도 증가하는 것 이 일반적인 경향이다 ${ }^{23)}$. Fig. 8에서 동일한 전계에서 비 교시, 두께가 얇은 비정질막의 경우가 절연성이 우수하며, 두께의 증가로 인한 거칠기의 증가 및 결정립도가 증가 했을 경우 누설전류가 증가함을 의미한다. 절연파괴강도 를 $100 \mu \mathrm{A}$ 이상의 누설전류가 검출될 때로 정의할 때, $1077 \mathrm{~nm}$ 두께를 갖는 $\mathrm{TiO}_{2}$ 박막은 약 $1000 \mathrm{kV} / \mathrm{cm}$ 이상의 절연파괴강도를 보였다. 테잎 캐스팅법에 의해 제조된 $100 \mu \mathrm{m}$ 두께의 후막에서 $700 \sim 1400 \mathrm{kV} / \mathrm{cm}$ 를 보이는 결과 ${ }^{21)}$ 와 비교할 때 양호한 특성이라고 할 수 있다.

\section{4. 결 론}

본 연구에서는 r.f. magnetron sputtering을 이용하여 $\mathrm{Si}$ 및 $\mathrm{PET}$ 기판위에 $\mathrm{TiO}_{2}$ 박막을 증착하고, 증착가스비 및 막 두께에 따른 성장거동과 전기적 특성을 평가하였다. $\mathrm{TiO}_{2}$ 박막의 결정구조는 증착가스비와 막 두께에 따라 영 향 받으며, $\mathrm{Ar}: \mathrm{O}_{2}=1: 1$ 의 가스비를 가지고 $\mathrm{Si}$ 기판에 증 착한 막은 Anatase상으로만 성장하였고, 같은 조건에서 약 
$100 \mathrm{~nm}$ 이하 두께의 막은 비정질상으로 성장하였다. PET 기판에서는 두께에 무관하게 비정질로 성장하며, 표면거 칠기는 산소분압증가에 따라 감소하였다. $\mathrm{TiO}_{2}$ 박막의 표 면은 주로 $\mathrm{Ti}^{4+}$ 상태로 형성되어 결함이 적은 화학적상태 를 이루고 있었으며, 표면에 부분적으로만 수산기 $\left(\mathrm{OH}^{-}\right)$의 존재를 보여 $\mathrm{TiO}_{2}$ 박막이 PET 표면위에 안정적으로 성장 하였다. 두께를 달리하여 제조한 막들의 유전상수는 $1 \mathrm{kHz}$ 에서 100 110의 유전상수를 보였다. 두께에 따른 결정화 도 및 거칠기의 변화로 인해 유전상수는 $\mathrm{TiO}_{2}$ 막의 두께에 따라 다른 변화양상을 보였다. 두께가 얇은 막의 경우, 주 파수증가에 따라 급격히 감소하는 모습을 보였다. 유전손 실값은 모든 시편에서 다소 높은 값을 보여, 유전체와 전 극의 계면상태조절을 위한 증착조건의 개선이 필요하다. 약 $1000 \mathrm{~nm}$ 두께를 갖는 막에서 절연파괴강도는 $1000 \mathrm{kV} / \mathrm{cm}$ 이상의 양호한 값을 보였다. 추가적인 특성파악이 필요하 지만, 본 연구에서 제조한 $\mathrm{TiO}_{2}$ 박막은 높은 유전상수와 절연파괴강도를 보여 고에너밀도를 요구하는 펄스파워 캐 패시터에의 적용가능성이 있음을 확인하였다.

\section{Acknowledgment}

이 논문은 2011년도 정부(교육과학기술부)의 재원으로 한 국연구재단의 지원을 받아 수행된 기초연구사업(No. 20110008164)이며 2010학년도 경북대학교 학술연구비에 의하 여 연구되었음.

\section{REFERENCES}

1. R. Vazquez-Reina, S. Chao, V. Petrovsky, F. Dogan, and S. Greenbaum, "Electrical and Electron Paramagnetic Resonance Spectroscopy Characterization oF Mn-doped Nanostructured $\mathrm{TiO}_{2}$ for Capacitor Applications," J. Power Sources, 210 21-5 (2012).

2. K. R. Bray, R. L. C. Wu, S. Fries-Carr, and J. Weimer, "Aluminum Oxynitride Dielectrics for Multilayer Capacitors with Higher Energy Density and Wide Temperature Properties," Thin Solid Films, 518 366-71 (2009).

3. A. Nishino, "Capacitors: Operating Principles, Current Market and Technical Trends," J. Power Sources, 60 137-47 (1996).

4. L. Lopez, W. A. Daoud, and D. Dutta, "Preparation of Large Scale Photocatalytic $\mathrm{TiO}_{2}$ Films by the Sol-gel Process," Surf. Coat. Technol., 205 251-57 (2010).

5. Z. Chen, Y. Tang, H. Yang, Y. Xia, F. Li, T. Yi, and C. Huang, "Nanocrystalline $\mathrm{TiO}_{2}$ Film with Textural Channels: Exhibiting Enhanced Performance in Quasi-solid/solid-state Dye-sensitized Solar Cells," J. Power Sources, 171 990-98 (2007).

6. Y. Leprince-Wang, D. Souche, K. Yu-Zhang, S. Fisson, G. Vuye, and J. Rivory, "Relations Between the Optical Properties and the Microstructure of $\mathrm{TiO}_{2}$ Thin Films Prepared by Ionassisted Deposition," Thin Solid Films, 359 171-76 (2000).

7. M. Hiratani, M. Kadoshima, T. Hirano, Y. Shimamoto, Y.
Matsui, T. Nabatame, K. Torii, and S. Kimura, "Ultra-thin titanium Oxide Film with a Rutile-type Structure," Appl. Surf. Sci., 207 13-19 (2003).

8. S. Chao and F. Dogan, "Processing and Dielectric Properties of $\mathrm{TiO}_{2}$ Thick Films for High-Energy Density Capacitor Applications," Int. J. Appl. Ceram. Technol., 8 [6] 1363-67 (2011).

9. M. Takeuchi, T. Itoh, and H. Nagasaka, "Dielectric Properties of Sputtered $\mathrm{TiO}_{2}$ Films," Thin Solid Films, 51 83-88 (1978).

10. R. F. Bunshah, "Handbook of Deposition Technologies for Films and Coatings," pp.270, 2nd ed., Noyes Publication, USA, 1994.

11. Y. Zhao, Y. Qian, W. Yu, and Z. Chen, "Surface Roughness of Alumina Films Deposited by Reactive R.f. Sputtering," Thin Solid Films, 286 45-48 (1996).

12. D. G. Syarif, A. Miyashita, T. Yamaki, T. Sumita, T. Choi, and H. Itoh, "Preparation of Anatase and Rutile Thin Films by Controlling Oxygen Partial Pressure," Appl. Surf. Sci., 193 287-92 (2002).

13. J. Sicha, J. Musil, M. Meissner, and R. Cerstvy, "Nanostructure of Photocatalytic $\mathrm{TiO}_{2}$ Films Sputtered at Temperature Below 200," Appl. Surf. Sci., 254 3793-800 (2008).

14. M. Horprathum, P. Eiamchai, P. Chindaudom, A. Pokaipisit, and P. Limsuwan, "Oxygen Partial Pressure Dependence of the Properties of $\mathrm{TiO}_{2}$ Thin Films Deposited by DC Reactive Magnetron Sputtering," Procedia Eng., 32 676-82 (2012).

15. K. Chan, T. Tou and B. Teo, "Thickness Dependence of the Structural and Electrical Properties of Copper Films Deposited by DC Magnetron Sputtering Technique," Microelectron. J., 37 608-12 (2006).

16. K. Navaneetha Pandiyaraj, V. Selvarajan, M. Pavese, P. Falaras, and D. Tsoukleris, "Investigation on Surface Properties of $\mathrm{TiO}_{2}$ Films Modified by DC Glow Discharge Plasma," Curr. Appl. Phys., 9 1032-37 (2009).

17. K. O. Awitor, A. Rivaton, J. L. Gardette, A. J. Down, and M. B. Johnson, "Photo-protection and Photo-catalytic Activity of Crystalline Anatase Titanium Dioxide Sputter-coated on Polymer Films," Thin Solid Films, 516 2286-91 (2008).

18. J. Guillot, F. Fabreguette, L. Imhoff, O. Heintz, M. C. Marco de Lucas, M. Sacilotti, B. Domenichini, and S. Bourgeois, "Amorphous $\mathrm{TiO}_{2}$ in LP-OMCVD TiN $\mathrm{O}_{\mathrm{y}}$ Thin Films Revealed by XPS," Appl. Surf. Sci., 177 268-72 (2001).

19. J. Jun, J. H. Shin, and M. Dhayal, "Surface State of $\mathrm{TiO}_{2}$ Treated with Low Ion Energy Plasma," Appl. Surf. Sci., 252 3871-77 (2006).

20. P. Madhu Kumar, S. Badrinarayanan, and M. Sasty, "NanocRystalline $\mathrm{TiO}_{2}$ Studied by Optical, FTIR and X-ray Photoelectron Spectroscopy: Correlation to Presence of Surface States," Thin Solid Films, 358 122-30 (2000).

21. S. Chao and F. Dogan, "Processing and Dielectric Properties of $\mathrm{TiO}_{2}$ Thick Films for High-energy Density Capacitor Applications," Int. J. Ceram. Technol., 8 [6] 1363-73 (2011).

22. V. M. Ferreira, J. L. Baptista, S. Kamba, and J. Petzelt, "Dielectric Spectroscopy of $\mathrm{MgTi0}_{3}$-based Ceramics in the $10^{9}-10^{14} \mathrm{~Hz}$ Region," J. Mater. Sci., $285894-900$ (1993).

23. C. L. Huang and Y. B Chen, "Structure and Electrical Characteristics of RF Magnetron Sputtered $\mathrm{MgTiO}_{3}$," Surf. Coat. Technol., 200 3319-25 (2006). 